\title{
Importance of heart rhabdomyoma in pediatric population. A 39-year experience. Case series
}

\author{
Importancia del rabdomioma cardiaco en población pediátrica. Experiencia de 39 años. \\ Serie de casos
}

\author{
Nadia G. Chía-Vázquez* , Gerardo Fuentes-Ramos², Emilia J. Patiño-Bahena , Atziri Guillén-González, \\ and Alfonso Buendía-Hernández ${ }^{1}$
}

${ }^{1}$ Department of Pediatric Cardiology, Instituto Nacional de Cardiología Ignacio Chávez; ${ }^{2}$ Department of Pediatrics, Hospital Infantil de México Federico Gómez; ${ }^{3}$ Department of Imaging, Instituto Nacional de Cardiología Ignacio Chávez, Mexico City, Mexico

\begin{abstract}
Introduction: Rhabdomyomas are the most prevalent benign heart tumors in the fetal stage and during childhood. Objective: Our objective is to make known our experience over 39 years in pediatric patients with rhabdomyoma in our institution, as well as to emphasize the importance of its detection, study and control due to the association it has with tuberous sclerosis (TS). Materials and methods: We conducted a retrospective, descriptive, and cross-sectional study, from January 1980 to March 2018. Twenty-four met our criteria; we collected information regarding the clinic and cabinet studies, as well as their evolution and the treatment given. They were called by telephone to know their evolution and current status. Results: We found 51 patients with a diagnosis of cardiac tumor, of which 24 were rhabdomyomas. The diagnosis was made prenatal in eight patients, five at birth, and in 11 during the $1^{\text {st }}$ year of life. The most frequent clinical manifestations were the presence of murmur, arrhythmias, cyanosis, dyspnea, and diaphoresis. In 17 of them a diagnosis of TS was made. Half had follow-up by neurology, ten by dermatology, eight by ophthalmology, and four with genetics. Half were left under surveillance, seven were given medical treatment and five required surgery. Regarding the clinical evolution 17 patients remained stable, five presented spontaneous regression and two died. Conclusions: Rhabdomyoma is a rare benign tumor, its evolution can be malignant and associated with TS, it darkens the prognosis.
\end{abstract}

Key words: Rhabdomyoma. Tuberous sclerosis. Bourneville disease.

\section{Resumen}

Introducción: Los rabdomiomas son los tumores cardiacos benignos más prevalentes en la etapa fetal y durante la infancia. Objetivo: Nuestro objetivo es dar a conocer nuestra experiencia durante 39 años en pacientes pediátricos con rabdomioma en nuestra institución, así como enfatizar la importancia de su detección, estudio y control por la asociación que tiene con esclerosis tuberosa (ET). Material y métodos: Realizamos un estudio retrospectivo y descriptivo, de enero de 1980 a marzo del 2018. Veinticuatro cumplieron con nuestros criterios, recogimos información respecto a la clínica y estudios de gabi-

Correspondence:

*Nadia G. Chía-Vázquez

E-mail: nadia.chia.93@gmail.com
Date of reception: 21-11-2019

Date of acceptance: 05-11-2020

DOI: $10.24875 /$ ACME.M21000176
Available online: $25-05-2021$

Arch Cardiol Mex (Eng). 2021;91(1):75-82 www.archivoscardiologia.com 2604-7063 / @ 2020 Instituto Nacional de Cardiología Ignacio Chávez. Published by Permanyer. This is an open access article under the CC BY-NC-ND license (http://creativecommons.org/licenses/by-nc-nd/4.0/). 
nete, así como su evolución y el tratamiento dado. Se les llamó vía telefónica para conocer su evolución y estado actual. Resultados: Encontramos 51 pacientes con diagnóstico de tumor cardiaco, de los cuales 24 eran rabdomiomas. El diagnóstico se hizo prenatal en 8 pacientes, 5 al nacimiento y en 11 durante el primer año de vida. Las manifestaciones clínicas más frecuentes fueron la presencia de soplo, arritmias, cianosis, disnea y diaforesis. En 17 de ellos se hizo diagnóstico de ET. La mitad tuvo seguimiento por neurología, 10 por dermatología, 8 por oftalmología y 4 con genética. La mitad se dejó en vigilancia, a 7 se les dio tratamiento médico y 5 requirieron cirugía. En cuanto a la evolución, 17 pacientes se mantuvieron estables, 5 presentaron regresión espontánea y 2 fallecieron. Conclusiones: El rabdomioma es un tumor benigno poco frecuente, su evolución puede ser maligna y asociado a ET ensombrece el pronóstico.

Palabras clave: Rabdomioma. Esclerosis tuberosa. Enfermedad de Bourneville.

\section{Introduction}

Primary cardiac tumors are uncommon at all ages, with their prevalence in the general population being $0.002 \%$. In the pediatric age, the prevalence has been reported to be $0.027-0.08 \%$ in autopsies, and up to $0.3 \%$ in echocardiographic studies; these neoplasms have been detected in up to $0.14 \%$ in fetal studies, with a prevalence of $1: 10,000^{2-4}$. Most these tumors are benign $(90 \%)$. Histologically, the most common benign tumors at the pediatric stage are rhabdomyomas (60\%), made up of the characteristic "spider" cells (Fig. 1), followed by fibromas (12\%), myxomas $(10 \%)$, intracardiac teratomas $(25 \%)$, and hemangiomas ${ }^{5}$.

Rhabdomyoma was described by von Recklinghausen in 1862 associated with neurofibromatosis ${ }^{6,7}$. This tumor is usually circumscribed, lobulated, whitish or grayish in color, and in up to $90 \%$ of cases, it is multiple. It can affect any point of the heart muscle with ventricular predominance, especially the left ventricle, and it can compromise the ventricular function, valvular function or cause flow obstruction ${ }^{8,9}$. Tumors found in the atria can compress the coronary arteries and cause myocardial ischemia ${ }^{9}$.

Rhabdomyomas start appearing between the $20^{\text {th }}$ and $30^{\text {th }}$ weeks of gestation, with earliest diagnosis having been made at week 15. Growth has been observed to be slow from week 32 to the end of pregnancy and to stop after birth, with this behavior probably being related to pregnancy hormones 9,10 .

Bidirectional echocardiography is a non-invasive study and has been shown to be the preferred diagnostic method, and thanks to its growing availability it has increased the detection of these tumors ${ }^{1}$ (Fig. 2). Magnetic resonance imaging (MRI) and multidetector computed tomography (MDCT) have enabled better evaluation of these lesions ${ }^{11}$.

The described mortality is variable, with the most important risk factors for poor perinatal outcome being the size $(>20 \mathrm{~mm})$, arrhythmias, and hydrops ${ }^{10}$.
Most patients with rhabdomyomas do not require surgical management, since most involution at around 6 years of age $4,12,13$. The treatment to be provided will depend on the hemodynamic impact caused by the tumor and on the presence of serious arrhythmias; this will also determine the prognosis ${ }^{10}$.

Tuberous sclerosis (TS), also known as Bourneville disease, is an uncommon multi-systemic disease with a prevalence of 1:10,000-50,000 in the general population, and in children, 1:680010.13. Association with cardiac rhabdomyoma is between 50 and $70 \%$. When a cardiac tumor appears in the context of a syndrome like TS, the presentation is different from that of those that occur sporadically. TS is characterized by the presence of hamartomas in multiple organs, with cerebral predominance, with presence of cortical tuberosities and subependymal nodules, renal angiomyolipomas, retinal hamartomas, subungual fibromas, and epidermal nevi, among others, with hypomelanotic skin lesions and cortical tuberous brain lesions being the only manifestations at neonatal stage $^{4,14}$.

In $90 \%$ of cases, it occurs due to de novo mutations, with the mutation being detected in the TSC1/hamartin gene (9q34.3 locus: 605,284) in half the cases, and in the other half, in the TSC2/tuberin gene (12q15 locus: 147,570 and $16 p 13.3$ locus: 191,092). Its form of inheritance is autosomal dominant with a broad variety of expression, and with familiar tendency being as high as $50 \% 9,10,12$.

\section{Objective}

Our goal is to share our experience throughout 39 years in pediatric patients with this diagnosis within our institution, as well as to emphasize the importance of its detection, study, and control due to the association it has with TS and the repercussions of the latter in the long term. 


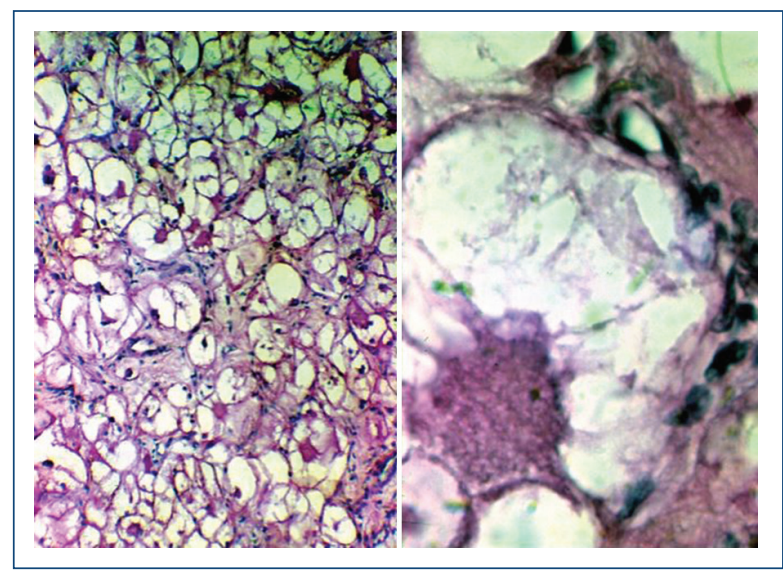

Figure 1. Rhabdomyoma cells histology. Characteristic "spider cell" with displaced nucleus, vacuolated, with granulations in the cytoplasm and thin extensions of the cytoplasm (courtesy of Dr. Alberto Aranda, pathologist at the National Institute of Cardiology).

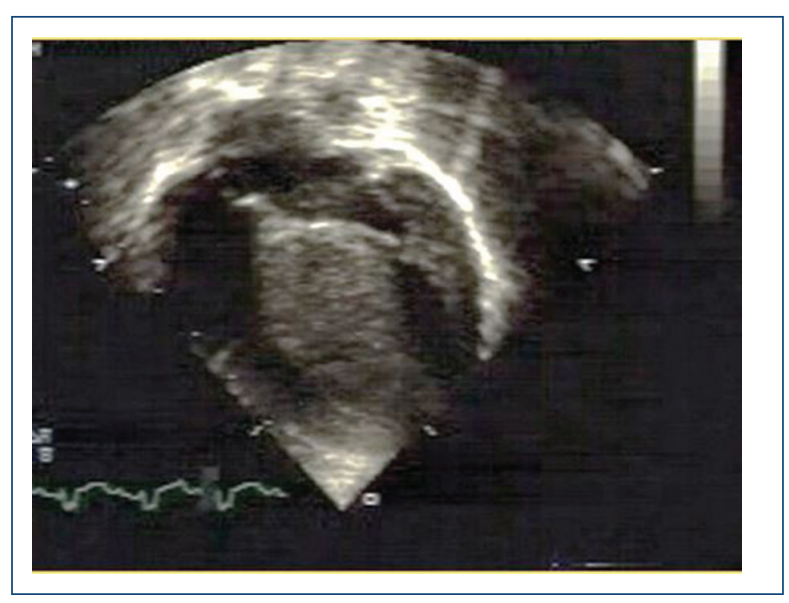

Figure 2. Four-chamber image with giant rhabdomyoma in the right ventricle on echocardiogram.

\section{Materials and Methods}

We carried out a retrospective, descriptive study where we reviewed digital, physical, and negative records, covering a period from January 1980 to March 31, 2018. To select our study population, we used the following criteria:

\section{Inclusion criteria}

The following criteria were included in the study:

- Patients with a diagnosis of primary cardiac tumor under the care of our institution.
- Patients who at the time of diagnosis were younger than 18 years.

\section{Exclusion criteria}

Cardiac tumor of the myxoma, fibroma, or teratoma types was excluded from the study:

We collected information regarding age at diagnosis, gender, initial data presented by the patient, associated clinical findings of any other heart disease, clinical manifestations, transthoracic echocardiography (TTECHO), transesophageal, computed tomography (CT) and/or MRI findings, with the location, classification, and number of tumors being reviewed, as well as the evolution and management given to them, whether it was surgical or conservative. Finally, a follow-up phone call was made to find out their evolution and current status.

As for statistical analysis, all the information was compiled in a database, where percentages, means, minimums, and maximums were evaluated.

\section{Results}

A total of 51 patients were found with a cardiac tumor diagnosis, out of which 24 (47\%) were rhabdomyomas.

Among these patients, no difference in presentation was found regarding gender (12 females and 12 males). Diagnosis was made prenatally in eight patients (33\%), one due to neonatal arrhythmia and ventricular extrasystole and seven as an incidental finding during obstetric ultrasound, in five patients $(21 \%)$ at birth, and in 11 cases $(46 \%)$ during the $1^{\text {st }}$ year of life.

The most common clinical manifestations are shown in table 1.

The imaging study that was used to confirm the tumor diagnosis was TTECHO (Fig. 3). In 5 patients, it was confirmed by histopathological study.

Tumor location is shown in table 2.

Ten patients $(41 \%)$, in addition to the presence of rhabdomyomas had coexistence of any congenital heart disease: one had pulmonary stenosis (4\%), one had hypoplasia of the ascending aorta and aortic arch (4\%), two had patent oval foramen (8\%), two patients had atrial septal defect $(8 \%)$, three had patent ductus arteriosus (PDA) (12\%), and one patient with trisomy 21 had ventricular septal defect and PDA.

In 17 of them (71\%), TS was diagnosed, which was confirmed by imaging with CT and/or MRI of the brain, with the presence of interventricular calcifications being identified (Fig. 4) 
Table 1. Clinical manifestations. The most common symptoms and signs presented by the patients are shown. As for arrhythmias, which were those who had any is described, and their treatment mostly was with digitalis and one definitive pacemaker for complete AVB

\begin{tabular}{|c|c|c|c|c|}
\hline Patient & Murmur & Arrhythmia & Cyanosis/ dyspnea & Asymptomatic \\
\hline 1 & & Ventricular extrasystole & & \\
\hline 2 & & $3^{\circ} \mathrm{AVB}$ & & \\
\hline 3 & & & & $\mathrm{x}$ \\
\hline 4 & & Ventricular extrasystole and supraventricular tachycardia & & \\
\hline 5 & & Ventricular extrasystole and supraventricular tachycardia & & \\
\hline 6 & & Neonatal arrhythmia & & \\
\hline 7 & $\mathrm{x}$ & & & \\
\hline 8 & & IRBBB & $x$ & \\
\hline 9 & $\mathrm{x}$ & & & \\
\hline 10 & $\mathrm{x}$ & & & \\
\hline 11 & $x$ & IRBBB & & \\
\hline 12 & & Supraventricular tachycardia & & \\
\hline 13 & & & & $\mathrm{x}$ \\
\hline 14 & & & & $\mathrm{x}$ \\
\hline 15 & $\mathrm{x}$ & & & \\
\hline 16 & & & $\mathrm{x}$ & \\
\hline 17 & $x$ & Supraventricular tachycardia & & \\
\hline 18 & $x$ & & $x$ & \\
\hline 19 & & Supraventricular tachycardia & & \\
\hline 20 & $x$ & & & \\
\hline 21 & $x$ & & & \\
\hline 22 & $\mathrm{x}$ & & $x$ & \\
\hline 23 & $\mathrm{x}$ & & & \\
\hline 24 & & Atrial and ventricular extrasystole & & \\
\hline
\end{tabular}

AVB: atrioventricular block; IRBBB: incomplete right bundle branch block.

Clinical manifestations presented by the patients are shown in table 4.

Twelve patients $(50 \%)$ were followed-up by neurology, ten (41\%) by dermatology, eight $(33 \%)$ by ophthalmology, and four (16\%) by genetics in our institution, the rest were referred for follow-up at their corresponding pediatric hospital.

Half the patients were left under surveillance, seven $(29 \%)$ received medical treatment for seizure control and five $(21 \%)$ required surgical management for hemodynamic repercussion, two due to left ventricular outflow tract obstruction, two due to right ventricular outflow tract obstruction, and one due to hypoxia. Seventeen patients $(71 \%)$ remained stable, five $(21 \%)$ had spontaneous regression and two (8\%) died, one of the patients due to cardiac arrest because she had a complete atrioventricular block; in in this case, the rhabdomyoma was located at the ventricular septum, which involved and affected the conduction system. The other patient died due to irreversible cardiogenic shock secondary to ventricular failure after partial resection of the tumor. 
Table 2. Rhabdomyomas location. Mostly (19 cases, $79 \%)$, the tumors were multiple and in $5(21 \%)$ it occurred as a single tumor (these are shown highlighted)

\begin{tabular}{|c|c|c|c|c|}
\hline Patient & RV & $\mathbf{L V}$ & RV and LV & IV septum \\
\hline 1 & & $x$ & & \\
\hline 2 & & & & $x$ \\
\hline 3 & & $x$ & & \\
\hline 4 & & & $x$ & $x$ \\
\hline 5 & & & $x$ & \\
\hline 6 & & $x$ & & $x$ \\
\hline 7 & $x$ & & & $x$ \\
\hline 8 & $x$ & & & \\
\hline 9 & & & $x$ & \\
\hline 10 & & & $x$ & \\
\hline 11 & & & $x$ & \\
\hline 12 & $x$ & & 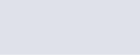 & \\
\hline 13 & & & $x$ & \\
\hline 14 & $x$ & & 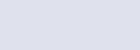 & \\
\hline 15 & & & $x$ & \\
\hline 16 & $x$ & & & $x$ \\
\hline 17 & $x$ & & & $x$ \\
\hline 18 & & & & $x$ \\
\hline 19 & $x$ & & & \\
\hline 20 & & & $x$ & \\
\hline 21 & & & $x$ & \\
\hline 22 & $x$ & & & \\
\hline 23 & & & $x$ & \\
\hline 24 & & & $x$ & \\
\hline
\end{tabular}

RV: right ventricle; LV, left ventricle.

\section{Discussion}

Cardiac tumors at pediatric age are mostly benign and, among them, rhabdomyoma is considered the most common, especially within the $1^{\text {st }}$ year of life. In most cases, patients are usually asymptomatic and the tumors are detected by the presence of murmurs, but manifestations may vary depending on the tumor site and the structures it affects, and may occur as syncope, heart failure, superior vena cava syndrome, pulmonary hypertension, pulmonary, cerebral or myocardial

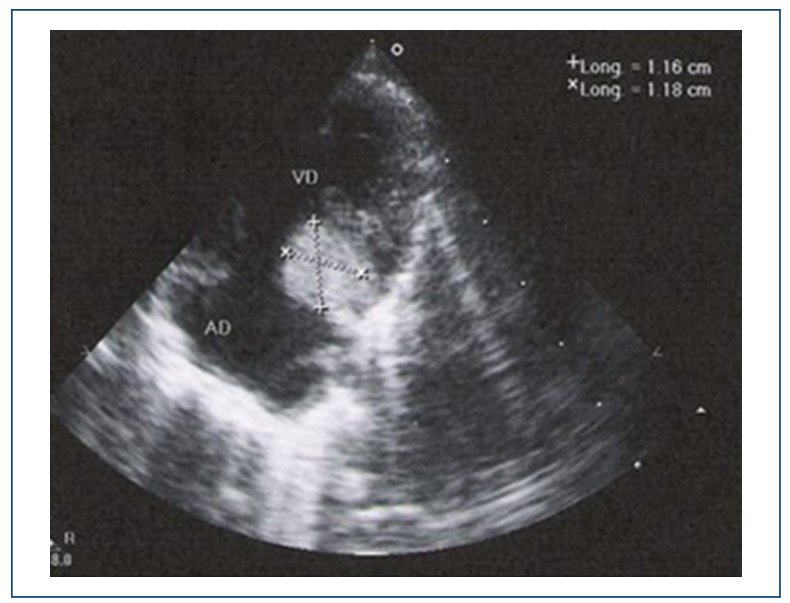

Figure 3. Echocardiographic image showing a thickening in posterior projection, which corresponds to a rhabdomyoma.

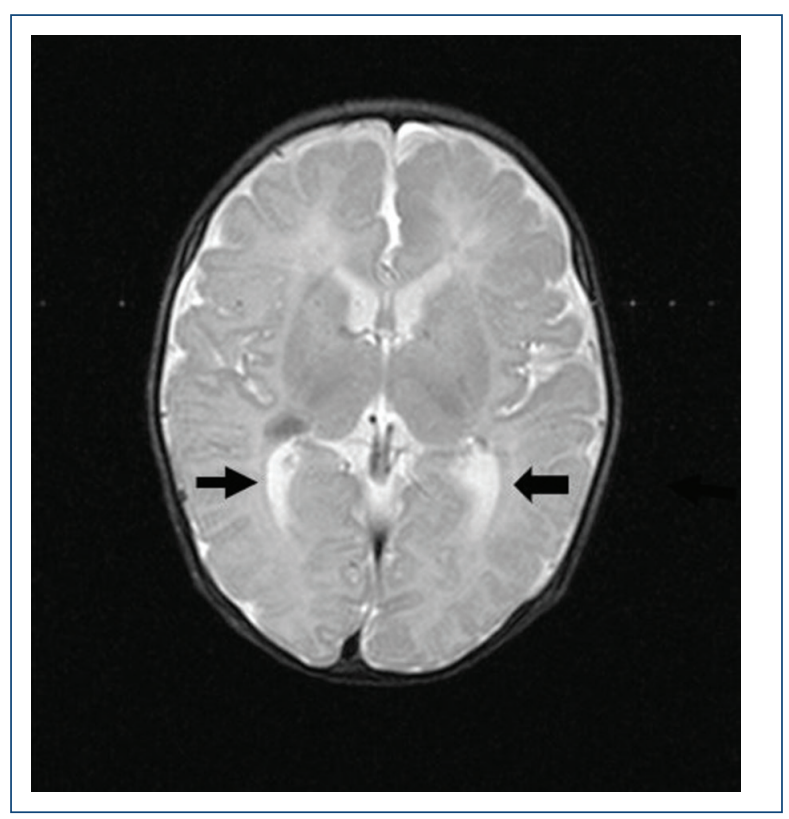

Figure 4. Cross-sectional tomography of the skull, where intracranial tuberosities, which are characteristic of TS, are observed.

ischemia, cor pulmonale, arrhythmias, embolism, thrombosis, and even sudden death. In prenatal life, it often occurs with arrhythmias or hydrops fetalis ${ }^{4,14}$.

Prenatal diagnosis can be made since third trimester during routine obstetric ultrasound, where the tumor, hydrops or arrhythmias can be detected, and advanced fetal echocardiography can be used in specific cases of risk, from week 14 of gestation on. Of the eight patients who were prenatally detected, in seven it was as 
Table 3. Tuberous sclerosis (TS) diagnostic criteria*

\section{Genetic criteria}

Identification of a mutation in TSC1 or TSC2 in DNA is sufficient to make a definitive TS diagnosis.

Ten to $25 \%$ of patients have no mutation identified by

conventional genetic testing, and a normal result does not exclude mutation in TSC

\begin{tabular}{|c|} 
Clinical criteria \\
\hline Major criteria
\end{tabular}

1. Hypomelanotic macules $(\geq 3$, at least $5 \mathrm{~mm}$ in diameter)

2. Angiofibromas $(\geq 3)$ or fibrous cephalic plaques

3. Ungual fibroma $(\geq 2)$

4. Shagreen patches

5. Multiple retinal hamartomas

6. Cortical dysplasia

7. Subependymal nodules

8. Subependymal giant cell astrocytoma

9. Cardiac rhabdomyoma

10. Lymphangioleiomyomatosis

11. Angiomyolipomas ( $\geq 2)$

\section{Minor criteria}

1. "Confetti skin" lesions

2. Holes in tooth enamel $(\geq 3)$

3. Intraoral fibromas $(\geq 2)$

4. Retinal achromic patch

5. Multiple kidney cysts

6. Non-renal hamartomas

*Definitive diagnosis: 2 major criteria or 1 major criterion with $\geq 2$ minor criteria. Probable diagnosis: 1 major criterion or $\geq 2$ minor criteria.

Adapted with permission from Northrup et al., 2013. ${ }^{9}$

an incidental finding during routine obstetric ultrasound, and in one patient it was detected due to the presence of arrhythmia and ventricular extrasystole with supraventricular tachycardia.

At postnatal stage, diagnosis is made as a finding in patients with murmur, obstructive valvular disease or in patients with signs and symptoms of TS or when there is a family history of TS, with $80 \%$ of cases being diagnosed within the $1^{\text {st }}$ year of life $e^{4.7}$. In our patients, $100 \%$ of them were diagnosed within the $1^{\text {st }}$ year of life, with heart murmur being the main reason for study.

With the help of echocardiogram, we can see the tumor site, size, and hemodynamic impact; MDCT and MRI play
Table 4. Tuberous sclerosis (TS) clinical characteristics

\begin{tabular}{|l|c|}
\hline \multicolumn{2}{|c|}{ TS clinical characteristics } \\
\hline & Series 1 \\
\hline Hypochromic spots & 7 \\
\hline Seizures & 10 \\
\hline Retinal hamartoma & 1 \\
\hline Angiofibroma & 1 \\
\hline Shagreen patches & 1 \\
\hline Digital fibroma & 1 \\
\hline Renal angiomyolipoma & 1 \\
\hline Hepatic angiomyolipoma & 1 \\
\hline Exotropia & 1 \\
\hline Mental retardation & 3 \\
\hline Asymptomatic & 5 \\
\hline
\end{tabular}

an important role as complementary studies, and are indicated when the diagnosis is not entirely clear or to add information for the surgical plan; with both these imaging techniques, we can visualize the lesion location, size, anatomical relationships and compromise of adjacent structures, and tissue can be better characterized ${ }^{15,16}$.

On MRI, the tumor is isointense on T1 and hyperintense on T2, compared to myocardium and does not enhance with contrast, which allows distinguishing it from fibroma when it is intramural. On MDCT, the tumor is hypodense compared to the myocardium, even after contrast $^{11,12}$ (Fig. 5). Despite having a better characterization with MRI, we prefer and recommend the use of echocardiography because MRI requires deep sedation that may decompensate a critically ill patient, and we restrict its use to patients in whom the benefit that is obtained overcomes the risk the patient is subjected to.

Tumor involution, either partial or total, has been described in up to $80 \%$, and the mechanism by means of which these tumors undergo regression is believed to be apoptosis ${ }^{4,12,13}$. In our study, $<25 \%$ exhibited involution (5/24); this percentage is explained by the fact that $4 / 24(16 \%)$ are still within the time window for developing involution given patients' current ages. In 5/24 (21\%), surgical resection was performed, and thus we could not see the involution capacity in these patients. The eight remaining patients discontinued follow-up in our institution, and we were unable to contact them, and thus we do not know the evolution of these patients.

There are reports on the use of rapamycin inhibitors as an alternative to surgery in symptomatic patients ${ }^{12,15}$. 


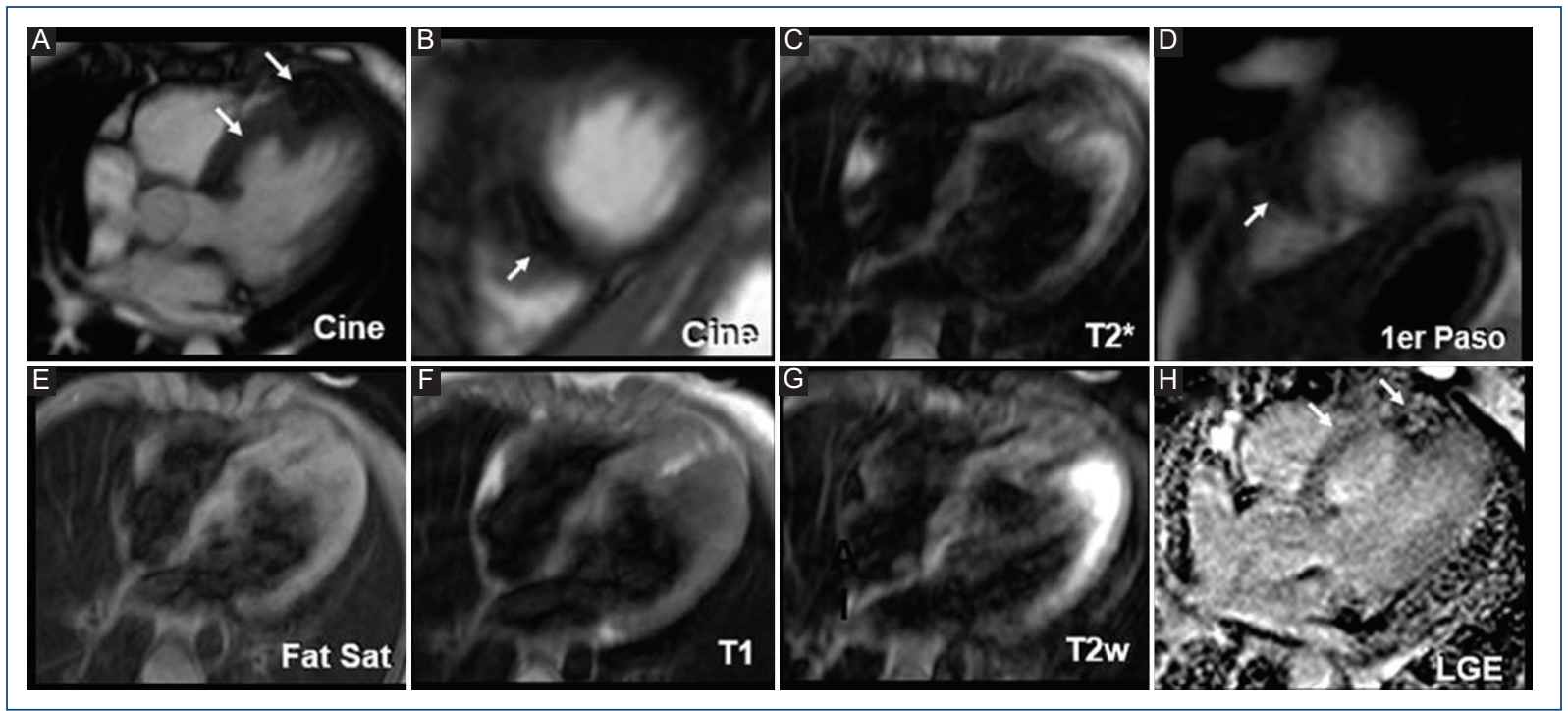

Figure 5. A: 4C cine magnetic resonance image of a 10-year-old male patient with interventricular septum aneurysm in the middle third toward the right ventricle and intramyocardial tumor on interventricular septum apical third. B: 2-chamber cine with apical septal intramural tumor $(9 \times 6 \mathrm{~mm})$. C: $2^{*}$ hypointense. D: hypointense intramural tumor first step. E: T1 hypointense FatSat. F: T1 hyperintense. G: T2 isointense W. H: late gadolinium enhancement image, hypertense, late linear intramyocardial enhancement on aneurysm wall.

Martínez et al. reported one patient with a prenatally-diagnosed giant rhabdomyoma who developed heart failure and duct-dependent circulation after birth. Pharmacological treatment with everolimus was administered, whereby the neoplasm had an involution of $0.80 \mathrm{~cm}^{2} /$ day. So far, it is the largest left ventricular tumor reported without surgical option and with significant involution ${ }^{17}$. Until 2017, we have not had the need to use it, on one hand because due to the age of some cases, the drug did not yet exist and subsequently it was not approved as treatment of choice, but we consider it as an alternative treatment for future cases.

Cardiac rhabdomyomas are observed in up to $50 \%$ of patients with TS and can be the first phenotypic manifestation of the syndrome. When a rhabdomyoma is detected by imaging, 40-90\% occur in the context of TS, and this association increases to $100 \%$ if more than one rhabdomyoma is found ${ }^{12}$. Among our patients, $83 \%$ had TS, which is consistent with the literature, but we disagree by having an association of $77 \%$ when there are multiple tumors, which can be due to the fact that, so far, the patients have not exhibited data consistent with TS, but maybe over time they will develop manifestations, since their age is short for TS to be ruled out, and surveillance is therefore important.

The most common symptom are seizures, which may not respond to medical management and cause severe mental retardation and development of progressive hydrocephalus secondary to brain tumors. In the absence of seizures, the incidence of mental retardation is low, but in the presence of mental retardation, seizures will always be present ${ }^{4}$. In our series, ten of the 17 patients with TS had seizures, three of them with mental retardation.

The presence of TS can be suspected with Vogt's triad: mental retardation, seizures, and skin lesions. There are criteria established since 1992 for its diagnosis (Table 3 ). MRI provides additional information, which helps to detect brain tuberous lesions associated with TS and extracardiac tumors ${ }^{10}$. It should be considered that the absence of prenatal stage brain or renal lesions does not exclude postnatal occurrence ${ }^{4,14}$.

Given the high association of rhabdomyoma with TS, multidisciplinary management with the neurology department for the treatment of these patients and implementing early rehabilitation to reduce the sequelae is important, as well as genetic counseling with the parents.

Congenital heart disease can coexist with cardiac tumors, and the association of rhabdomyomas with Ebstein's anomaly and pulmonary valve hypoplasia has been reported; although these associations are not well studied, we consider that, so far, these can be isolated relationships ${ }^{18}$. In our series, we found an association in ten cases. Some authors postulate that the presence of the tumor at embryological development early stages 
would have a possible interaction with the growth of normal structures of the heart ${ }^{16,19}$

Furthermore, the association of TS and aneurysms of the abdominal aorta has been reported in the literature since 1971 in school-age patients. At the National Institute of Cardiology, the case of an 8-month-old patient with multiple rhabdomyomas, TS and giant aneurysm of the abdominal aorta, compromising from the diaphragm to the iliac arteries, was reported ${ }^{20}$.

\section{Conclusion}

Rhabdomyoma is an uncommon tumor of benign histology, but when it has significant repercussion, its evolution can be malignant and its association with TS darkens the prognosis.

We recommend that all patients with TS should undergo an echocardiogram to rule out rhabdomyomas and, in parallel, an electrocardiogram to rule out arrhythmias.

When the rhabdomyoma diagnosis is confirmed, we recommend maintaining surveillance for spontaneous regression; despite this, it is important to maintain comprehensive monitoring of the patient, since in case of TS, other clinical complications can develop, and thus we consider evaluation by different specialties to be necessary, including: genetics, dermatology, neurology, ophthalmology, cardiology, dentistry, and nephrology.

\section{Acknowledgments}

We thank the Department of Pediatric Cardiology of the Institute, as well as the Department of Cardiovascular Imaging.

\section{Funding}

None.

\section{Conflicts of interest}

The authors declare that they have no conflicts of interest.

\section{Ethical disclosures}

Protection of human and animal subjects. The authors declare that no experiments were performed on humans or animals for this research.
Confidentiality of data. The authors declare that no patient data appear in this article.

Right to privacy and informed consent. The authors have obtained informed consent from the patients and/or subjects referred to in the article. This document is in the possession of the corresponding author.

\section{References}

1. Erdmenger Orellana J, Vázquez C, Ortega Maldonado J. Valor de la ecocardiografía en el diagnóstico contemporáneo de tumores cardiacos primarios en pediatría. Arch Cardiol Méx. 2005;75(2):154-8.

2. Tzani A, Doulamis IP, Mylonas KS, Avgerinos DV, Nasioudis D. Doulamis. Cardiac tumors in pediatric patients: A systematic review. World $\mathrm{J}$ Pediatr Congenit Heart Surg. 2017;8(5):624-32.

3. Castro FJ, Escudero Cárceles F, Espín López JM. Tumores cardiacos. En: Protocolos Diagnóstico y Terapéuticos en Cardiología. Murcia: Sociedad Española de Cardiología Pediátrica; 2006:194-9. Cap.22.

4. Cigarroa López JA, García Jiménez Y. Rabdomioma cardiaco tratado quirúrgicamente con éxito y revisión de la literatura. Arch Cardiol Méx. 2005;75(3):113-7.

5. Lizárraga-López SL, Zárate-Castañón $P$, Bobadilla-Aguirre A, Melgoza-Arcos ME. Rabdomiomas intracardiacos múltiples en un neonato con esclerosis tuberosa. Informe de un caso. Acta Pediatr Mex. 2010. 31:4,153-157.

6. Jansen F, Van Nieuwenhuizem O, Van Huffelen A. Tuberous sclerosis complex and its founders. J Neurol Neurosurg Psychiatry. 2004;75:770.

7. Sajmoló-Pablo M, Patiño E. El rabdomioma cardiaco. Experiencia 10 años en el Instituto Nacional de Cardiología Ignacio Chávez (tesis para subespecialidad). México: Instituto Nacional de Cardiología Ignacio Chávez.

8. Shapiro LM. Cardiac tumours: diagnosis and management. Heart. 2001;85:218-22

9. Northrup H, Krueger DA; International Tuberous Sclerosis Complex Consensus Group. Tuberous sclerosis complex diagnostic criteria update: Recommendations of the 2012 International Tuberous Sclerosis Complex Consensus Conference. Pediatr Neurol. 2013;49(4):243-54

10. Gómez E. Diagnóstico prenatal de rabdomioma fetal asociado a esclerosis tuberosa. A propósito de un caso. Rev Chil Obstet Ginecol. 2017;83:3.

11. Mercado-Guzman MP, Meléndez-Ramírez G. Evaluación de tumores cardiacos por tomografía computada multidetector y resonancia magnética cardiaca. Arch Cardiol Mex. 2016;86(4):335-49.

12. Lee E, Ghadimi Mahani M, Lu JC, Dorfman AL, Srinivasan A, Agarwal PP. Primary cardiac tumors associated with genetic syndromes: a comprehensive review. Pediatr Radiol. 2018;48(2):156-64

13. Patiño Bahena E. Tumores cardiacos. En: Attie F, Calderón J, Zabal C, Buendía A. Cardiología pediátrica. 2. ㄹ ed. México: Panamericana. 2013. pp. $465-470$.

14. Arango Posada CA. Rabdomiomas cardiacos y esclerosis tuberosa: presentación de dos casos en recien nacidos. Arch Med (Manizales). 2012;12(2):199-204.

15. Fatou Aw, Goyer I. Accelerated cardiac rhabdomyoma regression with everolimus in infants with tuberous sclerosis complex. Pediatr Cardiol. 2017;38:394-400.

16. Sánchez Andrés A, Insa Albert B, Carrasco Moreno Jl, Cano Sánchez A, Moya Bonora A, Sáez Placios JM. Tumores cardiacos primarios en la infancia. An Pediatr. 2008;69:1.

17. Martínez-García A, Michel-Macías C. Giant left ventricular rhabdomyoma treated successfully with everolimus: case report and review of literature. Cardiol Young. 2018;28(7):903-9.

18. Arnaiz GP, Toledo GI, Borzutzky SA, Urcelay MG, Heusser RF, Garay GF, et al. Comportamiento clínico de los tumores cardiacos desde el feto hasta el adulto: serie multicéntrica de 38 pacientes. Rev Méd Chile. 2006;134(9):1135-45.

19. Russel GA, Dhasmana JP, Berry PJ, Gilbertbarness EF. Coexistent cardiac tumors and malformations of the heart. Int $\mathrm{J}$ Cardiol. 1989;22:89-98.

20. Patiño E, Calderón-Colmenero J, Buendía A, Juanico A. Giant aortic aneurysm and rhabdomyomas in infant with tuberous sclerosis. Arch Cardiol Mex. 2005;75:448. 